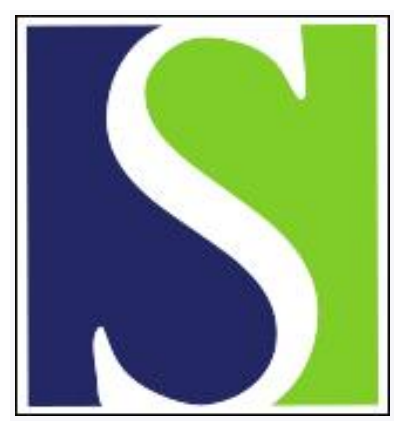

Scand J Work Environ Health 1982;8(1):29-36

https://doi.org/10.5271/sjweh.2499

Issue date: Mar 1982

Heart rate as an estimator of oxygen consumption during manual postal delivery.

by Oja P, IImarinen J, Louhevaara V

Key terms: heart rate; heavy work; manual postal delivery; oxygen consumption; prediction

This article in PubMed: www.ncbi.nlm.nih.gov/pubmed/7134920

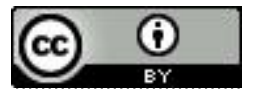




\title{
Heart rate as an estimator of oxygen consumption during manual postal delivery
}

\author{
by Pekka Oja, PhD, ${ }^{1,2}$ Juhani IImarinen, PhD,' Veikko Louhevaara, LSc ${ }^{1}$
}

\begin{abstract}
OJA P, ILMARINEN J, LOUHEVAARA V. Heart rate as an estimator of oxygen consumption during manual postal delivery. Scand $j$ work environ health 8 (1982) $29-36$. Nine young healthy postmen performed three progressive maximal exercise tests (on a bicycle ergometer and with and without a $10-\mathrm{kg}$ shoulder bag on a treadmill) for which the least-squares regression equations of heart rate (HR) on oxygen consumption $\left(\mathrm{VO}_{2}\right)$ were established. $\mathrm{HR}$ and $\mathrm{VO}_{2}$ were then measured during five modes of simulated postal delivery: on level ground by foot (F), bicycle (B), and push-cart (C) and on stairs by foot $(\mathrm{S} / \mathrm{F})$ and push-cart $(\mathrm{S} / \mathrm{C})$. The respective work $\mathrm{HR}$ values were inserted into the three regression equations established for $\mathrm{HR} / \mathrm{VO}$, and $\mathrm{VO}_{2}$ was solved for. The estimated $\mathrm{VO}_{2}$ values tended to be systematically higher than the measured ones. The best regression proved to be that established for the treadmill plus mailbag; the regression coefficients between the measured and estimated $\mathrm{VO}_{2} \mathrm{~s}$ were higher than 0.75 , and the percentage differences between the means of the measured and estimated values were no more than $10 \%$ for $\mathrm{F}$ and $\mathrm{B}$ delivery. All the regressions yielded inaccurate estimations of $\mathrm{VO}_{2}$ for $\mathrm{C}, \mathrm{S} / \mathrm{F}$ and $\mathrm{S} / \mathrm{C}$ delivery. It was concluded that $\mathrm{HR}$ is acceptable as an estimator of $\mathrm{VO}_{2}$ only when the test work closely resembles the muscle work in the job.
\end{abstract}

Key terms: heavy work, prediction.

The direct means available for measuring oxygen consumption $\left(\mathrm{VO}_{2}\right)$ under field conditions are rather cumbersome. Thus many attempts have been made to develop methods for estimating energy consumption. Heart rate is one attractive measure for this estimation because of its linear dependability on $\mathrm{VO}_{2}$, within limits, during certain types of muscular work. Indeed, heart rate has been used as the basis for estimating both the daily energy expenditure $(5,6,12,15)$ and $\mathrm{VO}_{2}$ of specified work such as coastal fishing $(3,13)$, housekeeping activities (2), building construction work (1), surgical operations (10), and postal delivery (11).

Fordham et al (7) compared the measured and predicted $\mathrm{VO}_{2}$ in light industrial work and found the "prediction... little

1 Department of Physiology, Institute of Occupational Health, Helsinki, Finland.

2 Current affiliation: Urho Kekkonen Institute for Health Promotion, Tampere, Finland.

Reprint requests to: Dr J Ilmarinen, Institute of Occupational Health, Laajaniityntie 1, SF01620 Vantaa 62, Finland. better than a lottery [p 290]." The correlation coefficients between the measured and predicted values were no better than 0.55 for any of the seven types of muscle work performed in the laboratory tests. There is, however, reason to believe that the correlation is better during heavier dynamic work. This paper reports an experiment in which we examined the validity of heart rate as an estimator of $\mathrm{VO}_{2}$ in manual postal delivery, which in Finland is known to demand typically a $\mathrm{VO}_{2}$ of more than $1.0 \mathrm{l} / \mathrm{min}$ (11).

\section{Material and methods}

Nine apparently healthy active postmen volunteered as subjects. They were all between the ages of 30 and 40 a. Some anthropometric characteristics of the subjects are given in table 1. After being medically screened, they performed, on separate occasions with a minimum interval of one week, first a submaximal bicycle ergometer test and then three progressive maximal exercise tests, one on 
Table 1. Characteristics of the subjects $(\mathrm{N}=9)$.

\begin{tabular}{lrr}
\hline & Mean & SD \\
\cline { 2 - 3 } & & \\
& 34.3 & 4.4 \\
Age (a) & 175.7 & 5.9 \\
$\begin{array}{l}\text { Height }(\mathrm{cm}) \\
\text { Weight }(\mathrm{kg})\end{array}$ & 72.4 & 10.6 \\
$\begin{array}{l}\text { Maximal oxygen consumption a } \\
\text { (I/min) }\end{array}$ & 3.29 & 0.49 \\
$\begin{array}{l}\text { Maximal oxygen consumption a } \\
\text { (ml/min - kg) }\end{array}$ & 45.8 & 4.8 \\
$\begin{array}{l}\text { Maximal heart rate a } \\
\text { (beats/min) }\end{array}$ & 188.4 & 6.9 \\
\hline
\end{tabular}

a Based on the highest individual values observed in any one of the three maximal tests.

a treadmill without an extra load, another on a treadmill with a $10-\mathrm{kg}$ mail bag, and the third on a bicycle ergometer.

The discontinuous bicycle ergometer test consisted of two 6-min submaximal work loads, with a 3 -min rest in between, and a maximal load with an increasing pedaling rate, $2 \mathrm{~min}$ at $50 \mathrm{r} / \mathrm{min}, 1 \mathrm{~min}$ at $70 \mathrm{r} / \mathrm{min}$, and $30 \mathrm{~s}$ at 100 or maximal $\mathrm{r} / \mathrm{min}$.

Both treadmill tests started with a 5 -min warm-up on a $5 \%$ grade at $5 \mathrm{~km} / \mathrm{h}$. After the warm-up the grade was increased by $2.5 \%$ every 2 min up to $20 \%$, while the speed was kept the same, and thereafter the speed was increased by $0.5 \mathrm{~km} / \mathrm{h}$ every 2 min. All tests were continued until the subject's subjective maximum was reached, unless signs or symptoms of excessive physiological strain caused the test to be discontinued earlier. On the treadmill most subjects reached their maximum at a walking speed. A few were able to proceed to a walk-jog pace.

A four-lead electrocardiogram (ECG) was monitored on an oscilloscope throughout the tests, and a paper recording was obtained during the last $15 \mathrm{~s}$ of each minute for heart rate measurement. Expired air was collected through a Tripple-J breathing valve in Douglas bags for 1 to $2 \mathrm{~min}$ at the end of the two submaximal bicycle work loads. On the treadmill two to three gas collections were made at selected submaximal work levels during which the work continued for 3 to $4 \mathrm{~min}$. During the last 1.5 to $2 \mathrm{~min}$ of the treadmill tests two consecutive air samples were obtained with a grade or speed increment in between, whenever possible. In the maximal bicycle work separate gas samples were taken for the $1 \mathrm{~min}$ at $70 \mathrm{r} / \mathrm{min}$ work and for the last 30 -s effort. For the calculation of $\mathrm{VO}_{2}$ the volume of expired air was measured with a dry gas meter, oxygen was analyzed paramagnetically (Taylor Servomex OA 150), and carbon dioxide was analyzed with an infrared $\mathrm{CO}_{2}$ analyzer (Datex $\mathrm{CD}$ 101). The highest obtained $\mathrm{VO}_{2}$ value during the maximal work in each test was chosen to represent the individual's maximal $\mathrm{VO}_{2}$.

Two individual least-squares regression equations of heart rate on $\mathrm{VO}_{2}$ were established for each test, one with the submaximal values only and the other with the maximal values included. When the $\dot{\mathrm{VO}}_{2} / \mathrm{HR}$ observation pairs were established, the mean of the two heart rates, one in the beginning of the gas collection and the other at the end of it, was utilized.

Field tests were conducted on two standard routes designed to simulate actual postal delivery. One route consisted of four mailboxes on a relatively level sidewalk totaling $273 \mathrm{~m}$ in one direction. The other route went through an apartment building that consisted of three staircases with four floors each. A mock mailbox was placed on each floor. Three modes of delivery were used on the level route: on foot with a shoulder bag (referred to hereafter as on-foot delivery), on foot with a three-wheel push-cart, and by bicycle with the mail bag in a rack on the front of the bicycle. On the stair route only on-foot and cart delivery were used. With the latter the cart was left outside the building in front of the staircase, and only the mail for that part of the building was carried.

Each delivery mode was performed four times, twice successively at the standard pace assessed by the postal authorities and twice successively at a free pace. During the delivery the subjects dropped three pieces of mail on the stair route and two pieces elsewhere each time they passed a mail box. Each delivery mode lasted 6 to $11 \mathrm{~min}$, depending on the mode and pace. The order of the delivery modes was randomized.

During the simulated delivery heart rate was measured telemetrically. A bipolar ECG signal was obtained with a portable heart rate meter (Medinik IC-600) and stored by a car-mounted tape re- 
corder (Uher CR 210). The data were processed automatically for the mean heart rate per minute for each successive 15-s period. The mean of these $15-\mathrm{s}$ heart rate values for each delivery bout was chosen to represent the work heart rate for that delivery.

Expired air was collected with a Kofranyi-Michaelis gas meter for the whole delivery time and analyzed for oxygen (Taylor Servomex OA 150) and for carbon dioxide (Datex CD-101). Since there were no systematic differences between the mean heart rates (over the entire delivery period) and the $\mathrm{VO}_{2} \mathrm{~s}$ of the two successive deliveries for each delivery mode, the mean of the two values was used to represent the heart rate and $\mathrm{VO}_{2}$ of that particular delivery mode.

In the estimation of $\mathrm{VO}_{2}$ for each delivery mode, the representative work heart rates were inserted into the regression equations calculated for heart rate on $\mathrm{VO}_{2}$ in the laboratory tests. Thus three estimates of $\mathrm{VO}_{2}$ were derived for the five delivery modes, on foot, by bicycle, and with cart on the level route and on foot and with cart on the stair route, each performed at a standard and free pace. The accuracy of the predicted $\mathrm{VO}_{2}$ was evaluated primarily by regression analysis of the predicted values on the measured ones.

\section{Results}

Fig 1 presents the comparison of the measured and predicted $\mathrm{VO}_{2}$ in milliliters per kilogram of body weight $(\mathrm{ml} / \mathrm{kg} \cdot \mathrm{min})$ for the five delivery modes. The slopes, intercepts, and correlation coefficients of the corresponding least-squares regression equations and the means of the measured and predicted values are given in table 2 .
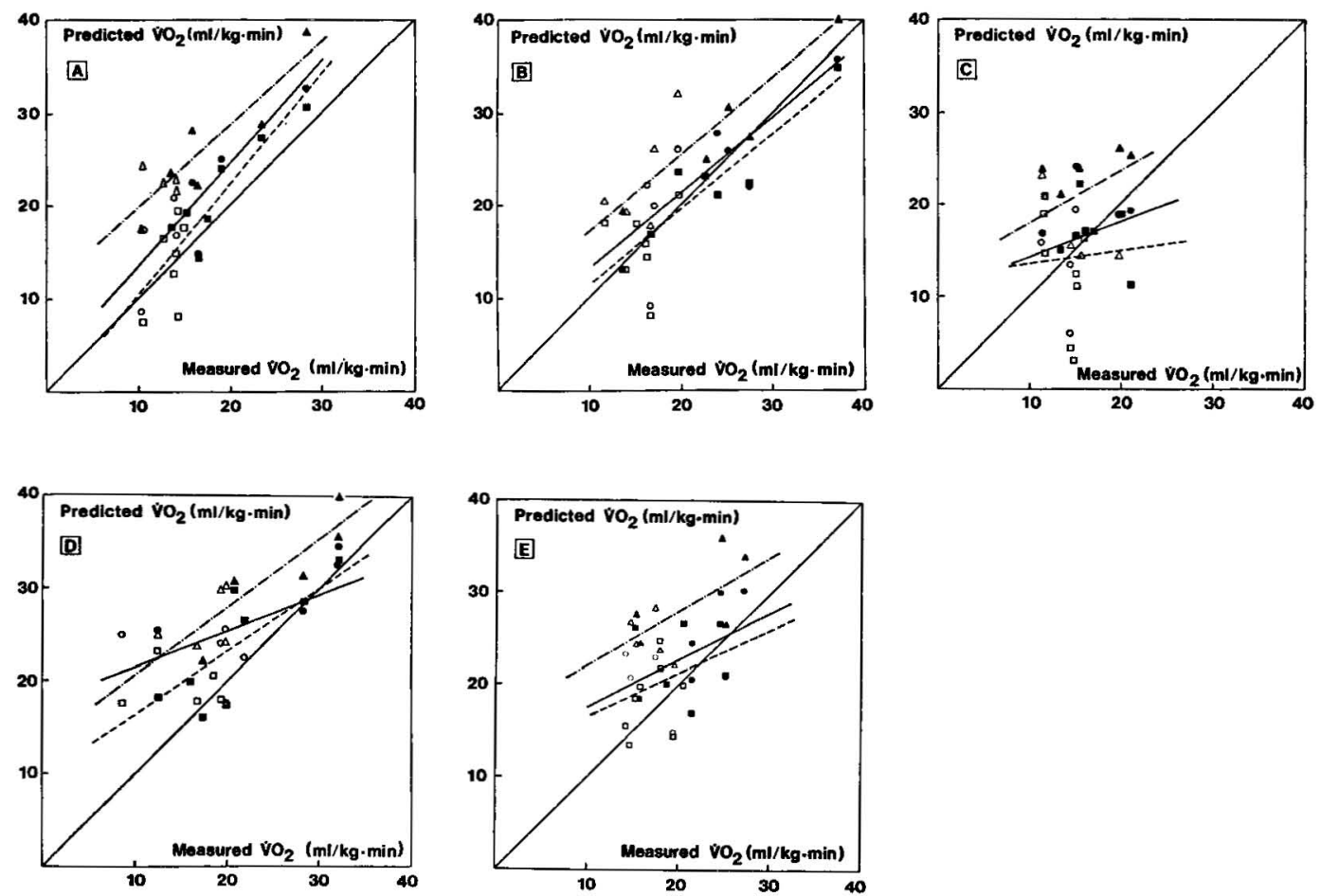

Fig 1. Comparison of the measured and predicted oxygen consumption values in milliliters per kilogram of body weight $(\mathrm{ml} / \mathrm{kg} \cdot \mathrm{min})$ for the five modes of simulated postal delivery $(A=$ on level ground by foot, $\mathrm{B}=$ on level ground by bicycle, $\mathrm{C}=$ on level ground by push-cart, $\mathrm{D}=$ on stairs by foot, $E=$ on stairs by push-cart). Circles stand for the treadmill regression, squares for the treadmill-with-bag regression, and triangles for the bicycle ergometer regression. The regression lines of the predicted values on the measured ones are drawn as a solid line, a broken line and a dash-dot line, respectively. Points marked by open symbols were obtained during the standard pace delivery and those by closed symbols during the free pace delivery. 
Both the free and standard pace values for each delivery mode have been included in the calculations of the regression lines.

The correlation coefficients were relatively high for all three regressions of on-foot and bicycle delivery; they were nearly as high for the stairs/on-foot delivery, but far too low for any predictive purposes for cart delivery of both kinds.
All regressions tended to overestimate $\mathrm{VO}_{2}$ - the bicycle regression systematically the most and the treadmill-with-bag regression the least.

The best single regression proved to be that established for treadmill work with the mail bag. Correlation coefficients of 0.86 and 0.84 and percentage deviations of 10 and -2 for on-foot and bicycle deliv-

Table 2. Intercepts (a), slopes (b), correlation coefficients ( $r$ ), the means of $Y$ and $X$, and the percentage differences of $Y$ from $X$ of the regression lines of the predicted oxygen consumption ( $\mathrm{VO} \mathrm{O}_{2}$ ) on the measured $\mathrm{VO}_{2}$ in milliliters per kilogram of body weight when the prediction was based on a maximal exercise test.

\begin{tabular}{|c|c|c|c|c|c|c|c|}
\hline Delivery mode & Type of test a & a & b & $r$ & $\mathrm{Y}$ & $\mathrm{X}$ & $\begin{array}{c}\text { Difference } \\
(\%)\end{array}$ \\
\hline On-foot & $\begin{array}{r}\text { TM } \\
\text { TMB } \\
\text { B }\end{array}$ & $\begin{array}{r}2.38 \\
-1.74 \\
10.87\end{array}$ & $\begin{array}{l}1.09 \\
1.20 \\
0.89\end{array}$ & $\begin{array}{l}0.87 \\
0.86 \\
0.88\end{array}$ & $\begin{array}{l}19.9 \\
17.8 \\
25.0\end{array}$ & $\begin{array}{l}16.0 \\
16.2 \\
15.9\end{array}$ & $\begin{array}{l}24 \\
10 \\
57\end{array}$ \\
\hline Bicycle & $\begin{array}{r}\text { TM } \\
\text { TMB } \\
B\end{array}$ & $\begin{array}{l}5.17 \\
3.46 \\
9.12\end{array}$ & $\begin{array}{l}0.81 \\
0.80 \\
0.82\end{array}$ & $\begin{array}{l}0.76 \\
0.84 \\
0.88\end{array}$ & $\begin{array}{l}23.6 \\
18.8 \\
25.9\end{array}$ & $\begin{array}{l}22.8 \\
19.2 \\
20.4\end{array}$ & $\begin{array}{r}4 \\
-2 \\
27\end{array}$ \\
\hline Cart & $\begin{array}{r}\text { TM } \\
\text { TMB } \\
B\end{array}$ & $\begin{array}{l}10.63 \\
12.31 \\
17.16\end{array}$ & $\begin{array}{l}0.40 \\
0.13 \\
0.33\end{array}$ & $\begin{array}{l}0.26 \\
0.00 \\
0.40\end{array}$ & $\begin{array}{l}16.7 \\
14.2 \\
22.0\end{array}$ & $\begin{array}{l}15.2 \\
15.3 \\
14.4\end{array}$ & $\begin{array}{r}10 \\
-7 \\
53\end{array}$ \\
\hline Stairs/on-foot & $\begin{array}{r}\text { TM } \\
\text { TMB } \\
B\end{array}$ & $\begin{array}{r}17.61 \\
9.95 \\
13.20\end{array}$ & $\begin{array}{l}0.40 \\
0.66 \\
0.74\end{array}$ & $\begin{array}{l}0.63 \\
0.74 \\
0.86\end{array}$ & $\begin{array}{l}26.1 \\
22.3 \\
29.4\end{array}$ & $\begin{array}{l}21.6 \\
18.7 \\
21.9\end{array}$ & $\begin{array}{l}21 \\
19 \\
34\end{array}$ \\
\hline Stairs/cart & $\begin{array}{r}\text { TM } \\
\text { TMB } \\
B\end{array}$ & $\begin{array}{l}12.29 \\
12.06 \\
15.93\end{array}$ & $\begin{array}{l}0.51 \\
0.45 \\
0.59\end{array}$ & $\begin{array}{l}0.47 \\
0.36 \\
0.63\end{array}$ & $\begin{array}{l}22.8 \\
20.3 \\
27.3\end{array}$ & $\begin{array}{l}20.7 \\
18.4 \\
19.4\end{array}$ & $\begin{array}{l}10 \\
10 \\
41\end{array}$ \\
\hline
\end{tabular}

a $\mathrm{TM}=$ treadmill without bag, $\mathrm{TMB}=$ treadmill with bag, $\mathrm{B}=$ bicycle ergometer.

Table 3. Intercepts (a), slopes (b), correlation coefficients ( $r$ ), the means of $Y$ and $X$, and the percentage difference of $Y$ from $X$ of the regression lines of the predicted oxygen consumption (VO⿰冫) on the measured $\mathrm{VO}_{2}$ in liters per minute when the prediction was based on a maximal exercise test.

\begin{tabular}{|c|c|c|c|c|c|c|c|}
\hline Delivery mode & Type of test a & $a$ & b & $r$ & $Y$ & $x$ & $\begin{array}{c}\text { Difference } \\
(\%)\end{array}$ \\
\hline On-foot & $\begin{array}{r}\text { TM } \\
\text { TMB } \\
B\end{array}$ & $\begin{array}{r}-0.11 \\
-0.27 \\
0.80\end{array}$ & $\begin{array}{l}1.40 \\
1.33 \\
0.89\end{array}$ & $\begin{array}{l}0.83 \\
0.90 \\
0.80\end{array}$ & $\begin{array}{l}1.41 \\
1.26 \\
1.84\end{array}$ & $\begin{array}{l}1.09 \\
1.15 \\
1.17\end{array}$ & $\begin{array}{l}29 \\
10 \\
57\end{array}$ \\
\hline Bicycle & $\begin{array}{r}\text { TM } \\
\text { TMB } \\
B\end{array}$ & $\begin{array}{r}-0.12 \\
0.34 \\
0.84\end{array}$ & $\begin{array}{l}1.16 \\
0.73 \\
0.70\end{array}$ & $\begin{array}{l}0.80 \\
0.76 \\
0.80\end{array}$ & $\begin{array}{l}1.73 \\
1.33 \\
1.87\end{array}$ & $\begin{array}{l}1.60 \\
1.37 \\
1.48\end{array}$ & $\begin{array}{r}8 \\
-3 \\
26\end{array}$ \\
\hline Cart & $\begin{array}{r}\text { TM } \\
\text { TMB } \\
B\end{array}$ & $\begin{array}{r}-0.24 \\
-0.18 \\
1.02\end{array}$ & $\begin{array}{l}1.35 \\
1.19 \\
0.59\end{array}$ & $\begin{array}{l}0.52 \\
0.33 \\
0.31\end{array}$ & $\begin{array}{l}1.20 \\
1.13 \\
1.63\end{array}$ & $\begin{array}{l}1.06 \\
1.10 \\
1.05\end{array}$ & $\begin{array}{r}13 \\
3 \\
55\end{array}$ \\
\hline Stairs/on-foot & $\begin{array}{r}\text { TM } \\
\text { TMB } \\
B\end{array}$ & $\begin{array}{l}1.32 \\
1.10 \\
1.08\end{array}$ & $\begin{array}{l}0.39 \\
0.43 \\
0.67\end{array}$ & $\begin{array}{l}0.53 \\
0.34 \\
0.81\end{array}$ & $\begin{array}{l}1.89 \\
1.67 \\
2.15\end{array}$ & $\begin{array}{l}1.48 \\
1.33 \\
1.60\end{array}$ & $\begin{array}{l}28 \\
26 \\
39\end{array}$ \\
\hline Stairs/with cart & $\begin{array}{r}\text { TM } \\
\text { TMB } \\
B\end{array}$ & $\begin{array}{l}0.94 \\
0.86 \\
0.98\end{array}$ & $\begin{array}{l}0.50 \\
0.45 \\
0.72\end{array}$ & $\begin{array}{l}0.44 \\
0.32 \\
0.67\end{array}$ & $\begin{array}{l}1.66 \\
1.47 \\
2.01\end{array}$ & $\begin{array}{l}1.43 \\
1.32 \\
1.43\end{array}$ & $\begin{array}{l}16 \\
11 \\
41\end{array}$ \\
\hline
\end{tabular}

a $\mathrm{TM}=$ treadmill without bag, $\mathrm{TMB}=$ treadmill with bag, $\mathrm{B}=$ bicycle ergometer. 
ery, respectively, can be considered satisfactory for practical purposes. For stairs/ on-foot delivery the correlation coefficient was somewhat lower $(0.74)$, the overestimate being about $20 \%$.

In table 3 and fig 2 the $\mathrm{VO}_{2}$ results are given in liters per minute. In comparison to the weight-related $\mathrm{VO}_{2}$ the general impression is similar; yet the correlation coefficients tended to be slightly lower, the percentage deviations somewhat larger, and the slopes steeper.

Table 4 summarizes the results of the correlation analysis between the measured
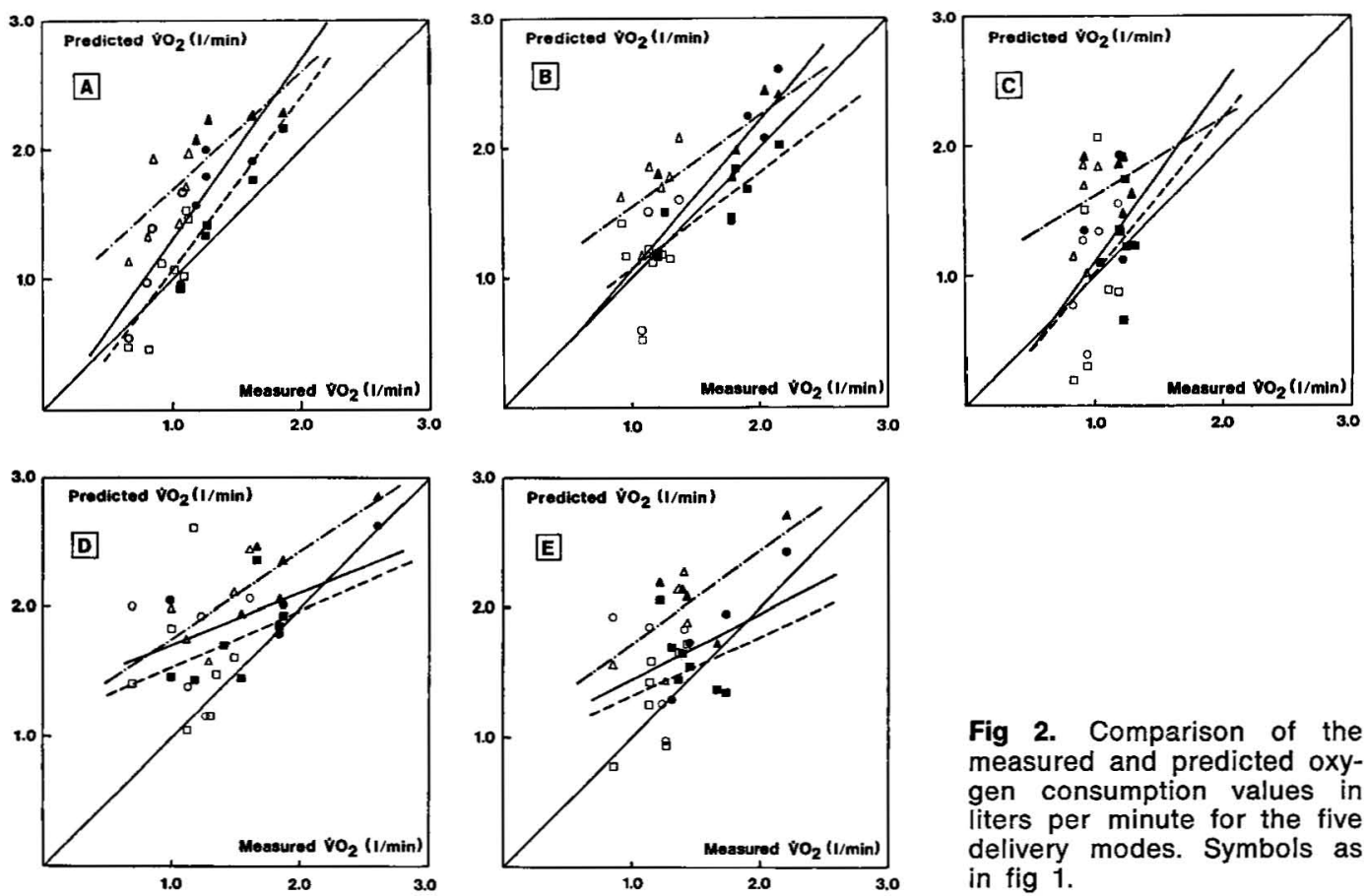

Fig 2. Comparison of the measured and predicted oxygen consumption values in liters per minute for the five delivery modes. Symbols as in fig 1.

Table 4. Intercepts (a), slopes (b), correlation coefficients ( $r$ ), the means of $Y$ and $X$, and the percentage differences of $Y$ from $X$ of the regression lines of the predicted oxygen consumption $\left(\mathrm{VO}_{2}\right)$ on the measured $\mathrm{VO}_{2}$ in milliliters per kilogram of body weight when the prediction was based on a submaximal exercise test.

\begin{tabular}{|c|c|c|c|c|c|c|c|}
\hline Delivery mode & Type of test a & $\mathrm{a}$ & b & $\mathbf{r}$ & $\mathrm{Y}$ & $x$ & $\begin{array}{c}\text { Difference } \\
(\%)\end{array}$ \\
\hline On-foot & $\begin{array}{r}\text { TM } \\
\text { TMB } \\
\text { B }\end{array}$ & $\begin{array}{r}5.22 \\
4.82 \\
11.27\end{array}$ & $\begin{array}{l}0.96 \\
0.88 \\
0.92\end{array}$ & $\begin{array}{l}0.92 \\
0.91 \\
0.79\end{array}$ & $\begin{array}{l}20.6 \\
19.1 \\
25.3\end{array}$ & $\begin{array}{l}16.0 \\
16.2 \\
15.2\end{array}$ & $\begin{array}{l}29 \\
18 \\
66\end{array}$ \\
\hline Bicycle & $\begin{array}{r}\text { TM } \\
\text { TMB } \\
\mathbf{B}\end{array}$ & $\begin{array}{r}8.03 \\
8.48 \\
12.47\end{array}$ & $\begin{array}{l}0.70 \\
0.61 \\
0.68\end{array}$ & $\begin{array}{l}0.79 \\
0.87 \\
0.75\end{array}$ & $\begin{array}{l}24.0 \\
20.2 \\
26.9\end{array}$ & $\begin{array}{l}22.8 \\
19.2 \\
21.3\end{array}$ & $\begin{array}{r}5 \\
5 \\
23\end{array}$ \\
\hline Cart & $\begin{array}{r}\text { TM } \\
\text { TMB } \\
B\end{array}$ & $\begin{array}{r}9.89 \\
14.36 \\
16.86\end{array}$ & $\begin{array}{l}0.50 \\
0.16 \\
0.42\end{array}$ & $\begin{array}{l}0.44 \\
0.10 \\
0.33\end{array}$ & $\begin{array}{l}17.5 \\
16.9 \\
23.0\end{array}$ & $\begin{array}{l}15.2 \\
15.3 \\
14.6\end{array}$ & $\begin{array}{l}15 \\
10 \\
58\end{array}$ \\
\hline Stairs/on-foot & $\begin{array}{r}\text { TM } \\
\text { TMB } \\
B\end{array}$ & $\begin{array}{l}18.54 \\
13.65 \\
14.12\end{array}$ & $\begin{array}{l}0.36 \\
0.51 \\
0.69\end{array}$ & $\begin{array}{l}0.62 \\
0.75 \\
0.81\end{array}$ & $\begin{array}{l}26.3 \\
23.2 \\
30.1\end{array}$ & $\begin{array}{l}21.6 \\
18.7 \\
23.2\end{array}$ & $\begin{array}{l}22 \\
24 \\
30\end{array}$ \\
\hline Stairs/with cart & $\begin{array}{r}\text { TM } \\
\text { TMB } \\
\text { B }\end{array}$ & $\begin{array}{l}12.80 \\
15.63 \\
20.64\end{array}$ & $\begin{array}{l}0.50 \\
0.33 \\
0.38\end{array}$ & $\begin{array}{l}0.50 \\
0.37 \\
0.36\end{array}$ & $\begin{array}{l}23.2 \\
21.8 \\
28.2\end{array}$ & $\begin{array}{l}20.7 \\
18.4 \\
20.0\end{array}$ & $\begin{array}{l}12 \\
18 \\
41\end{array}$ \\
\hline
\end{tabular}

a $\mathrm{TM}=$ treadmill without bag, $\mathrm{TMB}=$ treadmill with bag, $\mathrm{B}=$ bicycle ergometer. 
and predicted values when the individual heart rate/ $\mathrm{VO}_{2}$ regression lines were calculated without the maximal values, ie, with two to three submaximal points of the heart rate/ $\mathrm{V} \mathrm{O}_{2}$ relationship. The correlation coefficients were comparable or even slightly better than those based on the maximal tests. On the other hand, the extent of overestimation of the predicted values, which is seen in these results too, is somewhat larger with the submaximal prediction.

When the slope (b) and correlation coefficient $(r)$ of the regression line and the percentage deviation of the predicted $\mathrm{VO}_{2}$ were considered, the best predictive regression was that of the treadmill-withbag. The respective values were $0.88,0.91$ and $18 \%$ for the on-foot delivery, and $0.61,0.87$ and $5 \%$ for the bicycle delivery. The prediction was poorer for stair/onfoot delivery and even more inaccurate for cart delivery.

\section{Discussion}

It is well known that for a given $\mathrm{VO}_{2}$ the heart rate is higher in static than in dynamic work (9) and higher in work with small muscle mass than in that with large muscle mass (14). This phenomenon would lead to an error in the estimation of $\mathrm{VO}_{2}$ from the heart rate/ $\mathrm{VO}_{2}$ relationship whenever the test work and the actual work differ with respect to the type of contraction and the muscle groups involved. Additional variation in this relationship may be caused by, among other things, ambient temperature, stage of digestion, and psychological factors. This interrelationship seems to be so delicate that, in light industrial work requiring a gross $\mathrm{VO}_{2}$ of only 0.4 to $1.0 \mathrm{I} / \mathrm{min}$, the prediction is reasonably satisfactory only when the calibration regression is established in actual work and in an actual work environment (7).

The prediction of $\mathrm{VO}_{2}$ from the work heart rate appears to be somewhat better for household activities which require a $\mathrm{VO}_{2}$ of 0.6 to $0.9 \mathrm{l} / \mathrm{min}$, and for typical tasks of coastal fishing with a $\mathrm{VO}_{2}$ of more than $1.0 \mathrm{I} / \mathrm{min}$. A recalculation of Åstrand's original data for the former type of work (2) yields a correlation coefficient of 0.62 between the measured and estimated va-
Iues, and a mean overestimate of $16 \%$. In coastal fishing, on the other hand, Rodahl et al (13) reported the estimated $\mathrm{VO}_{2} \mathrm{~s}$ to be within $\pm 15 \%$ of the measured values with no systematic error. In both studies heart rate/ $\mathrm{VO}_{2}$ regressions were established for bicycle ergometer work.

The present experiment was conducted for manual postal delivery, which is the predominant delivery mode in urban districts in Finland. The mail is carried primarily on foot or by bicycle. A threewheel push-cart is presently being introduced as a new delivery technique. In general, the delivery work can be characterized primarily as dynamic leg work with a varying degree of upper trunk static effort, mainly due to the holding of the mail in a shoulder bag, which is carried continuously in on-foot delivery and intermittently in bicycle and cart delivery.

In our study the prediction of $\mathrm{V} O$, proved to be very inaccurate for cart delivery, a result suggesting that the heart rate/ $\mathrm{VO}_{2}$ relationship established in bicycle ergometer and treadmill work may be distorted by the pushing and handling of the cart. However it must be pointed out that the range of $\mathrm{VO}_{2}$ values in cart delivery is narrower than in the other delivery modes, and thus the results are not fully comparable. The prediction was more accurate for on-foot and bicycle delivery, but even then only the regression for the treadmill work with the mail bag can be considered reasonably accurate for predictive purposes. The correlation coefficients were fairly high, and as such acceptable, with the bicycle and treadmillwithout-bag regressions too, but the notable, and in some cases gross, overestimation makes their use as predictors of $\mathrm{VO}_{2}$ questionable.

Two potential factors may have led to the systematic overestimation of $\mathrm{VO}_{2}$ in the present experiment, temperature differences between the laboratory and the field conditions and/or larger static effort in the actual work than in the laboratory work. The outdoor temperature during the field tests, which were done in October and November, varied between 1 and $15^{\circ} \mathrm{C}$, while the laboratory tests were performed at a normal room temperature.

Harjula (8) observed slightly, but non- 
significantly, lower heart rates in properly clothed, healthy men accustomed to cold exposure when they did standard submaximal work at $0^{\circ} \mathrm{C}$ than when they did a corresponding amount of work at room temperature. If a decrease in heart rate is assumed for a given $\mathrm{VO}_{2}$ in the present field tests as compared to that of the laboratory conditions, the heart rate ( $y$ axis) $/ \mathrm{VO}_{2}$ (x-axis)regression would shift to the right for the field tests. This change would result in an underestimation of the $\mathrm{VO}_{2}$ based on the laboratory regression. Therefore the observed systematic overestimation cannot be due to the temperature effect, which in fact should lead to underestimation.

In the simulated mail carrying the frequent drops of mail in the boxes may have introduced an extra static component into the work. An obvious static effort was involved in the cart pushing. In addition, the weight $(3.5 \mathrm{~kg})$ of the gas meter was an added burden even though the total weight carried gradually decreased during the course of the delivery, as the mail was dropped.

According to Borghols et al (4) each kilogram of extra weight increases heart rate during walking by 1.1 beats/min. Therefore the combined effect of the assumed extra static effort and weight carrying in the field tests, in comparison to the laboratory tests, is likely to have led to the leftward shift of the heart rate $/ \mathrm{VO}_{2}$ regression and to the subsequent systematic overestimation of $\mathrm{VO}_{2}$. It can be calculated that in on-foot delivery a mean increase of 5 beats/min in the work heart rate would account for a $10 \%$ overestimation of $\mathrm{VO}_{2}$.

In summary, we found that estimating $\mathrm{V}_{2}$ during on-foot, bicycle, and cart delivery from individual heart rate/ $\mathrm{VO}_{2}$ regressions established for bicycle and treadmill work with and without a mailbag yielded values that were almost invariably too high. Estimation was reasonably accurate for on-foot delivery, with a mean overestimate of $10 \%$, and for bicycle delivery, when the treadmill-with-bag regression was used. The prediction of $\mathrm{VO}_{2}$ with the bicycle and treadmill regressions for all delivery modes and all regressions for cart delivery gave too large a scatter of the predicted points around the ideal line and/or an unacceptably large systematic error.

The present results lead us to conclude that heart rate is conditionally acceptable as an estimator of $\mathrm{VO}_{2}$. Even in apparently "pure" and rather heavy dynamic work such as manual postal delivery the prediction is reasonably good only when the test work resembles the actual work closely.

\section{Acknowledgments}

This study was supported financially by Finnish Telecommunications.

\section{References}

1. Åstrand I. Degree of strain during building work as related to individual aerobic work capacity. Ergonomics 10 (1967) 293303.

2. Astrand I. Estimating the energy expenditure of housekeeping activities. Am j clin nutr 24 (1971) 1471-1475.

3. Åstrand I, Fugelli P, Karlsson CG, RodahI K, Vokac Z. Energy output and work stress in coastal fishing. Scand $j$ clin lab invest 31 (1973) 105-113.

4. Borghols EAM, Dresen MHW, Hollander AP. Influence of heavy weight carrying on the cardiorespiratory system during exercise. Eur j appl physiol occup physiol 38 (1978) $161-169$.

5. Bradfield RB, Huntzicker PB, Fruehan GJ. Simultaneous comparison of respirometer and heart-rate telemetry techniques as measures of human energy expenditure. Am j clin nutr 22 (1969) 696-700.

6. Bradfield RB, Huntzicker PB, Fruehan GJ. Errors of group regressions for prediction of individual energy expenditure. Am j clin nutr 23 (1970) 1015-1016.

7. Fordham M, Goldsmith R, Koval J, O'Brien C, Tan GLE. Ambulatory monitoring in industry - Heart rate or oxygen consumption as indices of strain. In: Stott FD, Raftery EB, Sleight $\mathrm{P}$, Goulding L, ed. Proceedings of the second international symposium on ambulatory monitoring, ISAM 1977. Academic press, London 1978 pp 283-297.

8. Harjula R. Cardiorespiratory effects of cold and exercise in health and coronary heart disease. Doctoral dissertation. Institute of Occupational Health, Helsinki 1980. $125 \mathrm{p}$.

9. Kilbom $\AA$. Circulatory adaptation during static muscular contractions. Scand $j$ work environ health 2 (1976) 1-13.

10. Lereim P, Rö J. Physical work performed by surgeons during orthopaedic operations. Acta orthop scand 46 (1975) $31-37$.

11. Oja P, Louhevaara V, Korhonen O. Age 
and sex as determinants of the relative aerobic strain of nonmotorized mail delivery. Scand $j$ work environ health 3 (1977) 225-233.

12. Payne PR, Wheeler EF, Salvosa CB. Prediction of daily energy expenditure from average pulse rate. Am j clin nutr 24 (1971) 1164-1170.

13. Rodahl K, Vokac $Z$, Fugelli $P$, Vaage $O$, Maehlum S. Circulatory strain, estimated energy output and catecholamine excretion in Norwegian coastal fishermen. Ergonomics 17 (1974) 585-602.

14. Stenberg J, Åstrand PO, Ekblom B, Royce $J$, Saltin B. Hemodynamic response to work with different muscle groups, sitting and supine. J appl physiol 22 (1967) 61-70.

15. Warnold I, Lenner RA. Evaluation of the heart rate method to determine the daily energy expenditure in disease: A study in juvenile diabetics. Am j clin nutr 30 (1977) $304-315$.

Received for publication: 7 May 1981 